Jovana Čikić*

Ana Bilinović Rajačić

Filozofski fakultet

Univerzitet u Novom Sadu
UDK: 316.356.2 Vukosavljević S.

308(497.11)

DOI: 10.19090/gff.2020.1.209-224

Pregledni naučni rad

\title{
DOPRINOS SRETENA VUKOSAVLJEVIĆA SOCIOLOŠKOM ISTRAŽIVANJU PORODICE U SRPSKOM DRUŠTVU**
}

Sreten Vukosavljević nesumnjivo je ključno doprineo utemeljenju srpske sociologije sela. No, iako njegov rad obiluje nalazima od značaja za identifikovanje i razumevanje karakteristika i transformacije tradicionalnog (seljačkog) porodičnog života, čini se da je njegov doprinos profilisanju istraživanja u srpskoj sociologiji porodice nepravedno zanemeren. Stoga se u radu, na osnovu publikovanih istraživačkih nalaza, analiziraju glavne teme i metodološke smernice Vukosavljevića u istraživanju tradicionalne (seljačke) porodice. Ovaj segment njegovog istraživanja čvrsto je integrisan u autorove nalaze o opštim obeležjima tradicionalne, seljačke društvene strukture. Vukosavljevića, pre svega, interesuju deskripcija porodičnih oblika (porodične zadruge, inokosne porodice) i ključnih elemenata tradicionalnog porodičnog života (porodični starešina, planinka, zadrugari, seljanka, disciplina, zadružna privreda). Negujući kritički pristup, Vukosavljević u istraživanju tradicionalnog porodičnog života uočava i „tamnu stranu“ porodičnih odnosa. Za razliku od svojih prethodnika, autor se bavi i istraživanjem društvenih faktora koji doprinose transformaciji porodičnih oblika, uloga i funkcionalnosti. Iako bez formalnog sociološkog obrazovanja, Vukosavljević zasigurno razmišlja o porodici na sociološki način.

Ključne reči: porodična zadruga, sociologija porodice, seljačka društva, Sreten Vukosavljević, tradicionalna porodica

Nema sumnje da u srpskoj sociologiji postoji zavidan kontinuitet istraživanja porodičnog života (Čikić -Bilinović Rajačić, 2018). Pri tome, možemo da govorimo o četiri sukcesivne etape u razvoju domaće sociologije porodice: predsociološkoj, ranosociološkoj, posleratnoj/socijalističkoj i (post)tranzicijskoj/ savremenom etapi (Čikić, 2019). U ovom radu fokus je na drugoj etapi koja obuhvata period između dva svetska rata. To je razdoblje u kojem dolazi do

\footnotetext{
*jovana.cikic@ff.uns.ac.rs

** rad je deo istraživanja na projektima III46006 I OI179037 koje finansira Ministarstvo prosvete, nauke i tehnološkog razvoja Republike Srbije.
} 
formalnog ustanovljavanja srpske sociologije (Bogdanović, 1990). Ujedno, treću i četvrtu deceniju 20. veka obeležile su intenzivne društvene promene, na političkom, demografskom, ekonomskom i kulturnom planu. Neposredno po okončanju Prvog svetskog rata formirana je jedinstvena država - Kraljevina Srba, Hrvata i Slovenaca (potom, Kraljevina Jugoslavija) koja je obuhvatala regione različitih obeležja i stepena razvijenosti. I pored brojnih poteškoća i prepreka, ovo je period početaka modernizacije srpskog/jugoslovenskog društva. Nakon Prvog svetskog rata, „uprkos brojnim internim i eksternim teškoćama" dolazi do "napretka u procesu industrijalizacije" (Šljukić, 2019: 27). Razvoj industrije uslovio je migracije na relaciji selo-grad, ali i produbljivanje razlika u vertikalnoj društvenoj strukturi. Uprkos postepenom razvoju industrije, poljoprivreda je i dalje dominantna privredna grana, kako po broju radnoaktivnih, tako i značaju za ukupan društveni proizvod (Veselinov, 1987). Treću deceniju 20. veka obeležile su Prva agrarna reforma i kolonizacija - obe su uticale ne samo na promene u poljoprivredi (Veselinov, 1987), već i na začetke transformacije ruralne društvene strukture u celini (Mitrović, 1998). Iako su migracije na relaciji selo-grad prisutne, stanovništvo je i dalje većinski ruralno, ali ipak uz primetan blagi porast broja gradske populacije (Ginić, 1971). Primetan je rast koncentracije populacije u urbanim centrima. Takođe, postepeno širenje gradskog načina života uslovljava i postepene promene u sistemu ruralnih vrednosti i ruralnim kulturnim obrascima. Tržište ima sve značajniju ulogu kao faktor integrisanja i promene. Period između dva svetska rata obeležio je i razvoj školskog sistema i delimična demokratizacija obrazovanja. Posebna pažnja bila je posvećena ideji da se formira jedinstven obrazovni sistem i time prevladaju regionalne razlike. No, uprkos tome, udeo nepismenih je i dalje bio veoma visok. Čalić (2004: 215-222) navodi da je period između dva svetska rata vreme formiranja osnova sistema socijalne sigurnosti. I pored značajnih regionalnih razlika, u ovom periodu dolazi do intenzivnijeg zapošljavanja žena (Čalić, 2004: 244).

Navedeni procesi uticali su na postepeno preoblikovanje tradicionalnog porodičnog života. Pri tome, transformacija porodica u urbanim sredinama je brža, ali se zato za promene seoskih porodica može reći da su dramatičnije. Najuočljivije su promene u porodičnom sastavu i strukturi tako da u periodu između dva svetska rata paralelno egzistiraju kako porodične zadruge, tako i inokosne/male porodice, ali i njihovi prelazni oblici (Erlih, 1971). Osim toga, promene se odvijaju i na nivou funkcionisanja porodične grupe, vršenja porodičnih uloga, kao i obeležja porodične integrisanosti. 
Navedene promene porodične svakodnevnice uticale su na to da se istraživački fokus $u$ drugoj etapi razvoja srpske sociologije porodice pomeri sa ranije deskripcije porodičnih oblika (pre svega, porodične zadruge) na istraživanje uzroka, dinamike i pravaca njihovih promena. Pored Vere Erlih, ovu etapu obeležili su i radovi Sretena Vukosavljevića ${ }^{1}$. Iako se njegovi radovi prvenstveno vezuju za oblast ruralne sociologije, nalazi Vukosavljevićevih istraživanja seljačkog društva zapravo obuhvataju raznovrsne sociološke teme - rad, poljoprivredu, kulturu, pravo, stanovanje, pa tako i porodicu. Cilj ovog rada je da se prikažu Vukosavljevićevi nalazi u vezi sa proučavanjem porodičnog života $u$ selu, kao i da se ti nalazi pozicioniraju u okviru njegovog opšteg shvatanja karakteristika i promena seljačkih društava. Osnovu za istraživanje čine publikovani autorovi radovi.

\section{OPŠTE KARAKTERISTIKE VUKOSAVLJEVIĆEVE SOCIOLOGIJE SELJAČKOG DRUŠTVA}

Za razumevanje mesta koje istraživanje porodice ima u Vukosavljevićevom ukupnom istraživačkom opusu, potrebno je prvo ukazati na opšta obeležja njegove sociologije seljačkog društva, kao i pristupa u proučavanju srpskog sela. Učitelj, narodni poslanik, ministar za agrarnu reformu i kolonizaciju nakon Drugog svetskog rata, jedan od osnivača srpske sociologije sela, Vukosavljević je jedan od najživopisnijih autora naše međuratne sociološke misli. Kako navodi Mitrović (1998: 129-130), glavni uzori, ali i inspiracija Vukosavljeviću u istraživanju seoskog načina života bili su Cvijić i Bogišić. Na njihovom tragu, autor nastavlja tradiciju kompleksnih empirijskih istraživanja strukture tradicionalnog srpskog seljačkog društva. Na žalost, Vukosavljević u svojim radovima ne objašnjava na

\footnotetext{
${ }^{1}$ Sreten Vukosavljević (Prijepolje, 1881 - Rovinj, 1960). Pripremio je i publikovao devet knjiga, četiri udžbenika i nekoliko desetina članaka, studija i ogleda (Aranitović, 2012: 159188). Na predlog prof. dr Slobodana Jovanovića, prof. dr Đorđa Tasića i prof. dr Mihaila Konstantinovića imenovan je za honorarnog nastavnika Pravnog fakulteta Univerziteta u Beogradu (1939-1941) gde je držao predavanja iz ruralne sociologije (prvi u našoj akademskoj zajednici) i bio sekretar novoformiranog Instituta za filozofiju i sociologiju. Profesurom će se baviti i posle II svetskog rata, sve do penzionisanja (1951). Nakon rata, imenovan je za upravnika Instituta za proučavanje sela pri SAN (1947-1953). Bio je dopisni član JAZU (1956). Dobitnik je Sedmojulske nagrade za životno delo (1959), a 1960. godine Srpsko sociološko društvo ga je izabralo za doživotnog počasnog predsednika (Isić, 2012: 108-120). Od 1973. do 2005. godine održano je 22 simpozijuma pod nazivom Seoski dani Sretena Vukosavljevića u njegovom rodnom Prijepolju (Mitrović, ?: 90).
} 
sistematičan način obeležja svog istraživačkog metoda. Prema Mitroviću (2012a: 127), u belešci pod nazivom Iz metodologije (činjenice $i$ utisci) (1949) koja je pronađena u Vukosavljevićevoj zaostavštini, autor tek $\mathrm{u}$ osnovnim crtama daje smernice za prikupljanje iskustvene građe. Na osnovu toga, Mitrović (2012a: 128) zaključuje da je Vukosavljević najbliži Dirkemovom pozitivizmu iako se između njihovih metodoloških shvatanja ne može staviti znak jednakosti. Ono što čini Vukosavljevićev istraživački pristup specifičnim jeste dodatak principa ,istorijske škole prava“" (Mitrović, 2012a: 125) kojima autor nastoji da obogati nepristrasno proučavanje društvenog života radi njegovog što boljeg i dubljeg razumevanja. U prikupljanju podataka, Vukosavljević se oslanja na tradicionalne istraživačke metode - posmatranje i naučni razgovor, smatrajući da njihova primena onemogućava skretanje u ,čisto veštačke konstrukcije“, do kojih mogu dovesti jednostrano analiziranje arhivske i statističke građe (Mitrović, 2012a: 127).

Svoje tumačenje tradicionalne ruralne društvene strukture i njenih promena Vukosavljević je sistematično izložio u višetomnoj studiji pod nazivom Istorija seljačkog društva ${ }^{2}$. Pored ovog, deo njegovih zapisa o scenama iz seljačkog života naučnoj javnosti predstavljen je u Pismima sa sela (Vukosavljević, 1962/2012e) ${ }^{3}$. Iako bez formalnog sociološkog obrazovanja koje bi ga, i u teorijskom i metodološkom smislu, pripremilo za veliki zadatak koji je sam sebi postavio, Vukosavljević je instinktivno osetio da je za građenje sistema sociološkog saznanja o seljačkom društvu neophodno dobro poznavanje istorijskih prilika koje su uticale

${ }^{2}$ Od četiri planirana toma, za Vukosavljevićevog života objavljen je samo jedan Organizovanje seljačke zemljišne svojine (1953). Drugi tom - Sociologija stanovanja - prvi put je publikovan pet godina nakon autorove smrti (1965), a Sociologija seljačkih radova tek početkom 1980-ih (1983). Četvrti planirani tom - O društvenim zajednicama $i o$ oblicima ponašanja u njima prvi put je objavljen više od pola veka nakon smrti autora (2012). U reizdanju Vukosavljevićevih dela iz 2012. godine publikovano je ukupno šest tomova - osim prethodno navedenih, prvi put je objavljen tom pod nazivom Seoske ustanove $i$ uredbe, dok su u posebnom, šestom tomu ponovo objavljena Pisma sa sela zajedno sa Političkim i drugim spisima.

${ }^{3}$ Pisma sa sela obuhvataju ranije objavljene skice o seljačkoj svakodnevici, procesima u ruralnoj društvenoj strukturi i načinima reprodukcije ruralnosti koje je Vukosavljević objavljivao u domaćim časopisima. Najveći broj ovih tekstova objavljen je u novinama Pravda, Sandžak, Politika. Tekstovi su, kako navodi Lukić (2012b: 21), nastajali neposredno po Vukosavljevićevom dolasku sa terena „tako da ona donose još vruća i neposredna njegova zapažanja“. Od oko 200 ovih tekstova koji su objavljivani tokom 1930ih, u Pismima sa sela publikovano je odabranih 59 (Šaranović, 2012: 26). 
na njegovo oblikovanje, ali i geografskih obeležja ruralnog prostora, podataka o ruralnom stanovništvu, njihovom sistemu verovanja i običaja, državnom sistemu, pravnim normama, i sl. Stoga ne čudi što se u proučavanju seljačkog života Vukosavljević oslanjao na različite izvore - od analize aktuelnih zemljišnih odnosa, usmene i pisane tradicije, preko lingvističkih obrazaca sve do seljačkog ,naučnog““ rada (Vukosavljević, 2012a: 10-14). Raznovrsnost izvora bila je nužna s obzirom na nameru autora da sagleda kompleksnost seljačkog života. Obilje iskustvene građe koju je tokom decenija rada prikupljao omogućilo je Vukosavljeviću da upozna i predstavi „najskrivenije suštine seljačkog života“ (Lukić, 2012a: 18).

Centralno pojmovno mesto u Vukosavljevićevoj analizi zauzima način privređivanja (ratarstvo, stočarstvo, zanati, trgovina). Obeležjima preovlađujućeg načina privređivanja, autor objašnjava: a) promene u svojinskim odnosima (prelazak sa kolektivne na privatnu svojinu), b) specifičnu organizaciju seljačkih radova, c) formiranje specifičnog tipa naselja (ono je centar privrednog života) i načina stanovanja i d) oblikovanje seljačkog mentaliteta. Pritom, autorovo insistiranje na načinu privređivanja kao faktoru oblikovanja i promena ruralne društvene strukture ne treba shvatiti kao puki ekonomski determinizam. Naime, Vukosavljević način privređivanja posmatra u širem kontekstu seljačkog stvaralaštva (kako individualnog, tako i kolektivnog) koje prožima sve oblasti reprodukcije ruralnosti i koje je u direktnoj vezi sa ,,sistemom kulturnih vrednosti kojima se osmišljava i rad i seljakov društveni život“" (Milošević, 1997: 113).

\section{PORODICA U VUKOSAVLJEVIĆOJ SOCIOLOGIJI SELJAČKOG DRUŠTVA}

Vukosavljević nije pisao o porodici u okviru zasebne studije. Naime, autor je planirao da o porodici piše u okviru četvrtog planiranog toma kapitalne Istorije seljačkog društva ( $O$ društvenim zajednicama i o oblicima ponašanja u njima) koji bi bio:

neka vrsta sociološke sinteze koja bi se odnosila na seljačku zemljišu svojinu, seoska naselja, seljačke radove, seoske zajednice i ustanove (porodice i porodične zadruge, bratstva, plemena, sela, seoske opštine i knežine i njihove razne uredbe i oblike ponašanja), kao i na širu organizaciju seljačkog društva uopšte (Mitrović, 2012b: 21).

No, kako za života nije stigao da oblikuje i publikuje ovaj tom, Vukosavljević o porodici govori dok istražuje način stanovanja i privređivanja ili organizaciju seljačkih radova. Njegovo bavljenje seljačkom porodicom zasniva se na stavu da je sociologija „opis i istorija institucija“ (Vukosavljević, 2012d: 17). 
Ovim se stavom Vukosavljević približava Dirkemovom tumačenju sociologije kao nauke o društvenim institucijama. Posredno, Vukosavljevićevo viđenje sociologije može da znači da on poistovećuje društvo sa institucijama, tražeći u njihovom kontinuitetu (ali ne i statičnosti!) pretpostavke za opstanak zajednica.

Jedna od institucija na kojima počiva društvo jeste i porodica. Pored bratstva i plemena, porodicu (zadrugu) autor ubraja u "seljačke kolektive“ (Vukosavljević, 2012d: 50). Zajedničko im je da su to: „organizacije“ koje su „organizovane, ali spontano. Org(anizacija) nije izgrađena, nego se izgrađuje stalno“ čiji su „,̌lanovi svi zajedno svesni celine. Svesno solidarni... To su kolektivi u kojima je čovek sam po sebi, a ne u koje pristupa“ (Vukosavljević, 2012d: 52). Iako ne definiše porodicu, Vukosavljević pravi pojmovnu distinkciju između porodice i drugih oblika srodničke povezanosti, npr. plemena i bratstva. Pleme je najširi oblik krvne povezanosti - bazira se na širim srodničkim vezama, ali i topografskim osnovama. Bratstva su, prema Vukosavljeviću (2012d: 95) starija od plemena, jer ,nema, niti je bilo nigde, da je selj(ačko) društvo bilo organizov(ano) samo u plemena, a da bratstva nije bilo“. Prema autoru, što je kolektiv manji, to je solidarnost jača. Takođe, autor ističe da su srodnički odnosi tesno povezani sa prostornom organizacijom seljačkog društva što se prepoznaje u vezi srodničkih odnosa i organizovanja samog seoskog naselja (kako stambenih, tako i radnih zona).

Analizirajući tradicionalno društvo, Vukosavljević identifikuje dva glavna tipa seljačkih porodica - inokoštinu i porodičnu zadrugu koja je ,postala od inokosne porodice množenjem čeljadi. Bude i da se inokosne porodice srode, udruže u zadrugu... Ili da se podeljena zadruga opet sastavi“" (Vukosavljević, 2012c: 86). Međutim, on pominje i päju ${ }^{4}$ kao zadrugu nesrodnika ili, pak, specifičnu porodicu koja se formira „kada se podeli imanje i zadruga razdvoji, ali produže raditi zajedno“ (Vukosavljević, 2012d: 64). Pitajući se o prvenstvu porodičnog oblika - inokoštine ili zadruge - Vukosavljević zaključuje da „uopšte nije bilo vremena u kome je društvo bilo sastavljeno samo iz inokosnih porodica ili samo iz zadruga“ (Vukosavljević, 2012d: 66). U skladu sa opštim stavom o seljačkom društvu, autor zaključuje da je tip porodice određen načinom proizvodnje:

kada zemlje ima na raspoloženju koliko se god može iskrčiti i obraditi i zemlje za stočarstvo ekstenzivno, onda je glavno organizovati radnu družinu. To je razlog

\footnotetext{
${ }^{4}$ Vukosavljević (2012b: 525) navodi da se päje „sećaju od južne Makedonije i Crne Gore pa do Dunava i u srbijansku Posavinu“. Iako je bila prisutnija u tradicionalnom društvu, autor (Vukosavljević, 2012b: 525) pominje primere päje i posle II svetskog rata.
} 
zbog koga se živi u zadruzi... zadruge su se naviše bile zadržale u krajevima sa širokim, plećatim, planinskim kosama ili planinskim površinama, u krajevima u kojima se može skupiti oko jednog središta dosta i radne zemlje i pašnjaka (Vukosavljević, 2012c: 86; 87).

Vukosavljević posebnu pažnju posvećuje analizi zadružnog porodičnog života. Zadruga predstavlja specifičan tip porodične organizacije zasnovan na krvnom srodstvu, povezanosti po vertikalnoj i bočnoj srodničkoj liniji. Za zadrugu je karakteristično zajedničko privređivanje, trošenje proizvedenog, kao i stanovanje. Za zadrugu je takođe karakteristična izražena porodična solidarnost koja se bazira na komplementarnosti ekonomskih uloga koje obavljaju njeni članovi. Život u zadruzi je pružao veću sigurnost, bezbednost, ali i omogućavao smanjenje troškova (npr. porezi, slavski troškovi). Vukosavljević u objašnjenje porekla zadruge uvodi i kulturni element - religijsku pripadnost - ističući da „u krajevima gde žive izmešani pravoslavni i muslimani, zadruga je mnogo više u pravoslavnih“ (Vukosavljević, 2012c: 87), ali to je zbog stočarstva kao tipičnije delatnosti za pravoslavce. Muslimanska porodica je, po Vukosavljeviću, mnogo patrijarhalnija nego pravoslavna i odlikuje je specifičan sistem nasleđivanja kao posledica primene šerijatskog zakona.

Kao i njegovi prethodnici (Karadžić, 1818; 1867; Marković, 1995; Bogišić, 1884), i Vukosavljević govori o najvažnijim elementima zadružnog života: starešini, zadružnom zboru, disciplini, planinki, mješaji, zadružnoj privredi. I on ukazuje na patrijarhalnost odnosa u zadruzi:

zna se ko u ime koga govori, iako obično nema nikakvog formalnog ovlašćenja za to. Muž u ime svoje žene i dece, svekrva u ime svojih snaha... Načelno je da se pita svako u zadruzi ko želi da pita i ko insistira na tome. Koliko će se pitati, to je druga stvar... Koliko je zadruga složenija, to je manje onih koji se pitaju (Vukosavljević, 2012c: 88).

O starešini Vukosavljević govori slično drugim našim autorima koji su se bavili porodičnom zadrugom. Starešina nije nužno najstariji član. Njegovo delovanje se ,stalno prati, meri i procenjuje“, a ,,kada nije za posla, promene ga nekako iako formalnog glasanja i biranja često ne bude“ (Vukosavljević, 2012c: 89). Opisujući položaj porodičnog starešine u zadruzi, Vukosavljević ga zapravo poredi sa režiserom porodičnog života, a manje sa autokratom, ističući da naša porodična zadruga nije patrijarhalna $u$ onom smislu ,kako rimski zakoni tu patrijarhalnu vlast definišu“ (Vukosavljević, 2012d: 67). Vukosavljević zapravo ukazuje na postojanje specifične patrijarhalne demokratije, ključnog mehanizma u 
organizovanju svakodnevnog porodičnog života i obezbeđivanju pretpostavki za opstanak, ali i transformaciju zadruge.

Ekvivalent ulozi porodičnog starešine među ženskim članovima zadruge jeste planinka - njena radna funkcija je u vezi sa poslovima oko mleka i proizvodnje mlečnih proizvoda (tzv. belog mrsa), a njen značaj neposredno proizilazi iz važnosti stočarstva za opstanak zadruge. O specifičnosti njenog položaja (posebno, u odnosu na druge žene u zadruzi), svedoči i to što planinka odgovara jedino i direktno porodičnom starešini. Time je ona, zbog važnosti uloge koju obavlja, makar delimično, izuzeta iz sistema patrijarhalnih porodičnih odnosa. I ona, kao i starešina, može da bude smenjena, ali „ta promena ne izaziva poremećaje u zadruzi“ (Vukosavljević, 2012c: 92).

Vukosavljevićevo pisanje o zadruzi odlikuje specifično viđenje života u ovom tipu porodice. Prvo, on ističe da je zadruga homogena celina samo ako se posmatra spolja. Međutim, ako se posmatra iznutra, iz perspektive onih koji je čine i u njoj žive, onda, kako kaže autor, u njoj postoje

uže celine. Svaki bračni par sa svojom decom jedna je celina u okviru zadruge. Ima svoju zasebnu zgradu ili bar odeljenje za spavanje... Svaka sverkva sa svojim snahama čini jednu celinu. Sa njima radi izvesne poslove zajedno, a odvojeno od ostale zadruge (Vukosavljević, 2012c: 93).

Druga bitna specifičnost zadruge odnosi se na tumačenje prirode porodičnih odnosa. Naime, dok njegovi prethodnici, pa i sama Erlih (1971) pominju skladne i harmonične odnose među zadrugarima (zasnovane na međusobnom uvažavanju i/ili patrijarhalnoj disciplini), Vukosavljević smatra da su u zadruzi (kao i u svakoj drugoj porodici) prisutni sukobi i da ,zadružni život, sam po sebi, niti je privlačan sada, niti je ikada bio ni blizu onoliko koliko se to mislilo" (Vukosavljević, 2012c: 88). Usuđujući se da kritikuje jedan od stubova srpskog seljačkog društva, autor pravi značajan otklon od uobičajenog, romantičnog viđenja zadružnog života, apostrofirajući tako svoj metodološki stav da „pred činjenicama nikada 'ne treba zatvarati oči', da im treba 'prilaziti bez cenzure', te da utiske o pojavama uvek treba oslanjati na činjenice“ (Mitrović, 2012a: 127). Time Vukosavljević, zapravo, ističe kritičnost kao jedno od glavnih obeležja sociološkog istraživanja.

Do deoba porodičnih zadruga, odnosno, intenziviranja transformacije ovog porodičnog oblika, prema Vukosavljeviću (2012d: 87), dolazi usled dubokih i neotklonjivih razloga. Prema autoru, promene u načinu proizvodnje imaju ključnu ulogu u ovom procesu - naime, prelazak na ratarstvo i intenzivno stočarstvo uslovili su promene u organizaciji rada u domaćinstvu - mnoštvo radne snage više nije neophodno pa, samim tim, zadruga kao zajednica života, ali i rada, postaje suvišna, 
čak i opterećujuća. Prema Vukosavljeviću, do intenzivnijih deoba zadruga na inokosne porodice dolazi onda kada one postanu ekonomski neefikasne, odnosno, "smetnja preduzimljivosti i novačenju" (Vukosavljević, 1962: 159). Tržište, a posebno intenziviranje novčane privrede takođe imaju uticaj na deobu zadruge jer, kako kaže autor, „kada nestane obilja zemlje onda prestane biti najvažnije kako će se organizovati i održati radna družina. Ona se već može organizovati i novcem“ (Vukosavljević, 2012c: 97). Vukosavljević (2012d: 97) ističe da do deobe može doći i usled unutrašnjih činioca - ,neslaganja zadrugara“ ili usled „kakve velike štete koju učini koji zadrugar". Osim razvoja privrede, do ubrzane deobe zadruga dovodi i siromaštvo (Vukosavljević, 2012c: 97). Neki su u Vukosavljevićevim nalazima pročitali da autor identifikuje ženu kao glavnog krivca za raspad zadruga jer

žene su, i u zadruzi dok su, više podeljene nego ljudi. One imaju svoje posebne radove u tekstilnoj radinosti, one pravljaju onim što nije zadružno, nego je posebna svojina užih porodica: vunom, konopljom, tekstilnim izrađevinama. One imaju češće nego ljudi svoje 'osobine'. One nisu rodbina među sobom, te su manje povezane sentimentalnim vezama nego muški zadrugari (Vukosavljević, 2012c: 97).

Činjenica je da je žena u zadruzi bila centar užeg porodičnog nukleusa, ali to svakako ne može biti jedini, a još manje glavni razlog deobe zadruga. Prema Vukosavljeviću, prodor tržišne privrede, potreba za uvođenjem inovacija u poljoprivredu, ali i razvoj nepoljoprivrednog sektora ( $u$ ruralnoj i neruralnoj ekonomiji) daleko su uticajniji faktori transformacije ovog oblika porodične organizacije.

Opisujući seljanku, Vukosavljević ukazuje na njenu privatnu/porodičnu ulogu i položaj, kao i na njeno mesto u široj (seoskoj) zajednici. On je opisuje kao mučenicu na čijim plećima leži svakodnevica zadruge. Vukosavljević ukazuje na izrazito nepovoljan položaj nevesti u porodici - ,na nogama je od rane zore pre svih, uveče se smiri poslednja“ (Vukosavljević, 2012d: 480). Glavni faktor promene njenog nepovoljnog položaja bila je participacija u biološkoj reprodukciji, odnosno, rađanje potomka (posebno, muškog deteta). I Vukosavljević, kao i njegovi prethodnici, ukazuje na tajnovitost trudnoće i samog čina rađanja - ,ženi je valjalo ustati odmah po porođaju, a porađala se često po rečima pesme 'kod ovaca na ploči studenoj" "(Vukosavljević, 2012d: 476). Time, on skreće pažnju na društvenu nevidljivost uloge seoske žene u biološkoj reprodukciji ruralnosti (iako je ova uloga ključna i za ruralne zajednice i za sam položaj žena). Ona pripada privatnoj sferi, kao i druge tipično ženske uloge, što odgovara obeležjima tradicionalnog ruralnog 
rodnog režima. Vukosavljević piše i o seljačkim reproduktivnim normama i mehanizmima kontrole rađanja - oni se, prema njegovom zaključku, menjaju postepeno:

tehnika kontrole rađanja razvija se stupanj po stupanj... svuda prvo počnu pobačaji, pa tek prilično docnije razna sprečavanja začeća. Pobačaje, sasvim često, žene udešavaju same sebi. Načinima raznim, mehaničkim... kada se ovako razvije tehnika pobacivanja te ono postane jevtino i prilično bezopasno, onda i to učini da pobacivanja bude mnogo više (Vukosavljević, 2012d: 309).

Ujedno, Vukosavljević (2012d: 312) ističe da su promene u obrascima rađanja sastavni deo opštih društvenih promena koje se odvijaju u selu:

promena u natalitetu na selu nije neka promena izdvojena od ostalih. Ne štrči, jer je došla uporedo i zajedno sa ostalim promenama, gde nije sasvim skorašnja, uklopila se u ceo moralni i društveni život, isto kao što se uklopila u ekonomski život.

Time on, zapravo, ukazuje na početke prve demografske tranzicije u našem selu. Pored toga, autor ističe uticaj društvenog položaja na promene u obrascima rađanja - navodi da ,i u gradu i na selu prvo žene imućne“ (Vukosavljević, 2012d: 309) primenjuju različite tehnike za kontrolu rađanja.

No, uprkos teškom životu seljanke, Vukosavljević ističe da je njen položaj u porodici i u selu bolji i dostojanstveniji nego položaj žene u građanskoj porodici što je rezutat seljankine ,važne i neophodne funkcije u domaćinstvu i kući“ (Vukosavljević, 2012d: 479). O važnosti seljanke za porodično domaćinstvo svedoči i autorovo zapažanje da „u selu skoro nema neudatih. Svaki je čovek primoran da se ženi i nema goreg nesrećnika od udovca“" (Vukosavljević, 2012d: 477).

Autor ne zaboravlja da analizira i intimne odnose. On ističe da je $u$ tradicionalnom, seljačkom društvu odnos muškaraca i žena bio krajnje sveden, posebno pred drugima, u javnosti. Nežnost se u intimnim/partnerskim odnosima retko pokazivala (što ne znači da je nije bilo), ali, kako kaže Vukosavljević, muškarac naziva ženu grubim, čak i pogrdnim rečima ne bi li time „omalovažio seksualni momenat u odnosima. To je ostatak iz stare zadruge“ (Vukosavljević, 2012d: 480). S druge strane, sasvim je drugačije njegovo obraćanje ženi kao majci ili kao domaćici. Bračna vernost se visoko vrednuje i strogo kontroliše, posebno kada su žene u pitanju. Nevera (žene) u bračnim odnosima jedan je od najčešćih povoda za razvod, pored nemogućnosti rađanja. Pišući o braku na selu, Vukosavljević (kao i njegovi prethodnici) ističe da se „ni momak ni devojka nisu pitali hoće li u neki brak ili ne“, ali da „zla i nasilja“ u tome nije bilo jer je seljačko 
društvo „homogeno“ (Vukosavljević, 2012d: 319). Mešoviti brakovi (po etničkoj i/ili verskoj osnovi) su retki u seljačkom društvu.

O deci i detinjstvu u selu Vukosavljević piše uzgredno, objašnjavajući položaj žene u porodici. On ističe da je vaspitanje dece bilo u potpunosti u rukama majke / žene, dok je u nekim krajevima ,sramota da se čovek (muškarac - prim. aut.) zabavlja sa decom“ (Vukosavljević, 2012d: 477). Deca su „pripadala zadruzi“ i imala važnu instrumentalnu vrednost što se, kako navodi Vukosavljević, može videti i iz narodne izreke „Nije gazda ko ima volove, no je gazda ko ima sinove“ (Vukosavljević, 2012d: 483). I u odnosu roditelj - dete, kao i u odnosima među supružnicima nema mesta javnom pokazivanju nežnosti. Sa transformacijom seljačkog društva, postepeno se menjao i odnos prema deci - o deci se više brine. Promene u odnosu prema deci, Vukosavljević (2012d: 311) povezuje i sa promenama u obimu rađanja - što se rađanje više ograničava, to je „bolja nega i manja smrtnost dece“. Autor uočava i početak organizovane, državne brige o deci i njihove zaštite kroz ,određivanje dodatka na decu... Ali ta intervencija ne zahvata selo sem delimično, nego više zahvata grad“" (Vukosavljević, 2012d: 311).

\section{ZAKLJUČNA RAZMATRANJA}

Uprkos ranije vođenoj polemici o tome u kojoj meri Vukosavljevićev rad uopšte zaslužuje da bude okarakterisan kao sociološki (Gordić, 2012), ovde se takvo pitanje ne postavlja. Iako Vukosavljević nije imao formalno sociološko obrazovanje, na osnovu uvida u njegove tekstove i analize jasno je da se on bavio seljačkom porodicom uvek imajući u vidu širi društveni kontekst, razmišljajući sociološki. Autor je analizu porodičnog života - kako pojedinih fenomena, tako i njihovih promena - uvek dovodio u vezu sa organizacijom života i rada u seljačkom društvu, ali i društvenim faktorima van ruralne društvene strukture (npr. državne institucije). To se jasno vidi i na osnovu toga što Vukosavljević, iako naglašava proizvodne faktore „nikad ne zapostavlja ni kulturne faktore (društveni život $\mathrm{u}$ porodici i selu, gustina [agrarne] naseljenosti““ (Gordić, 2012: 321), odnosno, on sam ističe da razvoj seljačke privrede ,zavisi od čisto socijalnih činilaca, poput gustine stanovništva i političkih i kulturalnih prilika“ (Gordić, 2012: 321). Na osnovu ovoga, možemo da zaključimo da Vukosavljević čini kvalitativni iskorak u proučavanju srpske porodice u odnosu na autore prve, predsociološke etape - on ne ostaje samo u deskriptivnoj ravni, već pokušava da pruži osnovu za generičko objašnjenje promena u porodičnom životu analizirajući ključne determinante tih promena. Iako posebno ističe način privređivanja, Vukosavljević ne zaboravlja uticaj drugih činilaca na formiranje $i$ transformaciju porodičnih oblika $u$ 
tradicionalnom seljačkom društvu (kulture, tržišta, demografskih faktora i sl.), naglašavajući složenost determinističkog okvira.

Iako nemamo dovoljno sistematičnih i detaljnih eksplikacija o metodu od samog autora, $\mathrm{u}$ Vukosavljevićevom radu se uočava izvesni kontinuitet $u$ odnosu na istraživače prethodne, predsociološke etape. To se, pre svega, odnosi na primenu posmatranja, razgovora i analizu sekundarne/istoriografske građe. Time autor neguje praksu predsocioloških istraživanja srpske porodice - naime, nastavljajući da opisuje seljački porodični život, porodične uloge i odnose, porodične funkcije, Vukosavljević stvara bogatu empirijsku osnovu za istraživanje njihovih modaliteta.

Međutim, za razliku od svojih prethodnika, Vukosavljević nešto više pažnje posvećuje ulozi i položaju žene u seoskoj porodici, kako iz pozicije porodične funkcionalnosti, tako i iz pozicije promene u porodici (posebno, raspada porodične zadruge). Na taj način, Vukosavljević čini seosku ženu društveno vidljivom i, pri tome, otvara jedno važno polje sociološke analize koje je aktuelno i danas, u radovima savremenih srpskih sociologa (Babović, Vuković, 2008; Novakov, 2011; Blagojević, 2008; 2010).

Posebna specifičnost Vukosavljevićevog istraživanja zadruga ogleda se u negovanju kritičkog pogleda na ovaj tip tradicionalne porodice. Za razliku od (većine) autora koji su veličali i idealizovali porodične zadruge, žaleći zbog njihovog raspada, Vukosavljević (2012d: 89) ističe da upravo takvi "nisu razumevali njihovu evoluciju“. Pored toga, autor ističe da je upravo nekritički pogled na porodičnu zadrugu doveo do toga da se u procesu njene transformacije izgubi ono što se ,dobro iz toga zadružnog režima modernizovano (moglo - prim. aut.) očuvati i razviti“ (Vukosavljević, 2012d: 89).

Analiza porodičnih funkcija je kod Vukosavljevića poprilično svedena, $\mathrm{u}$ smislu da se on fokusira na istraživanje biološko-reproduktivne i ekonomske funkcije. Vukosavljevića posebno interesuje ova druga funkcija što odgovara njegovom opštem shvatanju o karakteristikama srpskog seljačkog društva i glavnom faktoru njihovog formiranja i promene. Interesantno je da autor uočava i naglašava dualnost ekonomske funkcije (funkcije proizvodnje i funkcija potrošnje).

Kao i za njegove prethodnike (Čikić, 2019), tako se i za Vukosavljevića može reći da ga odlikuje samoniklost shvatanja i tumačenja seljačkog načina života i mesta koje porodica ima u seljačkom društvu. Iako mu se može zameriti izostanak analize porodične organizacije i života u gradovima što bi omogućilo komparaciju obeležja i pravaca razvoja, Vukosavljevićevu usmerenost na seljačku porodicu treba razumeti u svetlu njegovog osnovnog interesovanja za seljačko društvo i njegovu transformaciju u uslovima rane modernizacije srpskog društva. 
Jovana Čikić, Ana Bilinović Rajačić

\title{
CONTRIBUTION OF SRETEN VUKOSAVLJEVIĆ TO THE SOCIOLOGICAL RESEARCH ON FAMILY IN SERBIAN SOCIETY
}

\begin{abstract}
Summary
Sreten Vukosavljević was one of the most vivid authors of Serbian interwar sociology. He was a teacher, member of national parliament, minister of agrarian reform and colonization. His scientific work was mostly influenced by Cvijić's anthropogeography and Bogišić's research on legal customs. Vukosavljević is considered to be the founder of Serbian rural sociology, although he also contributed to the sociological analysis of work, housing, culture, law and family. However, his effort in researching peasant family was often underappreciated.

Vukosavljević based his research on peasant family on a postulate that sociology describes and analyses social institutions. Like Durkheim, he was interested in researching institutions' characteristics and continuity. Family is one of the crucial social institutions. Vukosavljević described the differences between family and other types of peasants' collectives (e.g. tribe, fraternity). He distinguished two major types of peasant families - individual family (inokoština) and joint family (porodična zadruga). The yype of family was determined by the type of production. The author was more focused on description and analysis of joint family (porodična zadruga) - traditional family based on blood kinship, mutual production, consumption and housing. Joint family was characterised by distinctive solidarity based on complementary economic roles of family members. Vukosavljević described key elements of joint family’s organisation and functioning - head of family (porodični starešina), housewife (planinka), family gathering (zadružni zbor), discipline, and family economy (zadružna privreda). He also wrote about specific characteristics of patriarchal order in joint family. Vukosavljević's work on joint family was specific, as he stated that joint family was not a homogenous entity - additionally, he criticized the romantic view on joint family, arguing that conflicts are integral part of family life.
\end{abstract}

Vukosavljević also made a qualitative breakthrough in researching traditional family by identifying and analysing factors of its transformation. He argued that the characteristics of production were the most significant factor, but he did not forget the impact of cultural patterns (religion), market economy, inner conflicts, demographics and poverty. The author stated that women had a significant part in the transformation of joint family, but they were not to be blamed for families' dissolution. Unlike his previous colleagues, Vukosavljević paid more attention on researching rural women's roles and position within peasant family and rural community. He wrote about rural women's contributions to economic and biological reproduction of rurality, referring to the factors of their change. Vukosavljević did not put much effort in researching childhood in peasant society - he described children's instrumental role, but also acknowledged that reduced birth rates correlated with the changes in parentchildren relations. 
Although Vukosavljević did not have formal sociological education, he wrote about family and peasant society in a sociological manner. Even though the author himself did not provide detailed information on his researching methods, it is obvious that he continued the researching practice of his previous colleagues, using observation, interview and secondary data analysis. Such approach enabled him to collect rich data. The major downside of Vukosavljević's work was the lack of a more thorough analysis of family functioning and nuclear/small families. Also, Vukosavljević did not pay much attention to researching urban families, as he focused on peasant society and its early modernization.

Key words: joint family, peasant society, sociology of family, Sreten Vukosavljević, traditional family

\section{LITERATURA}

Aranitović, D. (2012) Bibliografija Sretena Vukosavljevića. U: Isić, M. -Mitrović, M. -Aranitović, D. (2012). Život i delo Sretena Vukosavljevića 1881-1960. Beograd: Službeni glasnik. 159-270. [Na ćirilici]

Babović, M. -Vuković, O. (2008). Žene na selu kao pomažući članovi poljoprivrednih domaćinstava: položaj, uloge i socijalna prava. Beograd: UNDP Srbija.

Blagojević, M. (2008). Ženske seoske organizacije u Vojvodini. Novi Sad: Zavod za ravnopravnost polova.

Blagojević, M. (2010). Žene na selu u Vojvodini: svakodnevni život i ruralni razvoj. Novi Sad: Zavod za ravnopravnost polova.

Bogdanović, M. (1990). Sociologija u Jugoslaviji - institucionalni razvoj. Beograd:

Institut za sociološka istraživanja Filozofskog fakulteta u Beogradu.

Bogišić, V. (1884). O obliku nazvanom inokoština u seoskoj porodici Srba i Hrvata. Beograd: Štamparija Napredne stranke. [Na ćirilici]

Čalić, M. Ž. (2004): Socijalna istorija Srbije 1815-1941. Beograd: Clio. [Na ćirilici]

Čikić, J. (2019). Počeci sociološkog proučavanja porodice u Srbiji - od Vuka do Cvijića. Baština. 47: 233-252. [Na ćirilici]

Čikić, J. -Bilinović Rajačić, A. (2018). Novija istraživanja porodice u Sociološkom pregledu - doprinos jačanju discipline. Sociološki pregled 52 (1): 216-251. [Na ćirilici]

Erlih, V. (1971). Jugoslovenska porodica u transformaciji - studija u 300 jugoslovenskih sela. Zagreb: Liber.

Ginić, I. (1971). Dinamika urbanizacije u Jugoslaviji. Sociologija i prostor, 9(3132), 53-61. 
Gordić, A. (2012). „Metafizika“ seoskog života u delu Sretena Vukosavljevića. U: Antonić, S. (ur.) (2012). Sto godina sociologije u Srbiji. Beograd: Srpsko sociološko društvo, 314-336. [Na ćirilici]

Isić, M. (2012). Sreten Vukosavljević - nacionalna, prosvetna i politička delatnosti. U: Isić, M. -Mitrović, M. -Aranitović, D. (2012). Život i delo Sretena Vukosavljevića 1881-1960. Beograd: Službeni glasnik. 11-120. [Na ćirilici]

Karadžić, V. (1818). Srpski rječnik. Beč: Štamparija jermenskog manastira. [Na ćirilici]

Karadžić, V. (1867). Život i običaji naroda srpskog. Beč: Naklada Ane udove V. S. Karadžića. [Na ćirilici]

Lukić, R. (2012a). Predgovor. U: Vukosavljević, S. (2012b). Istorija seljačkog društva III - Sociologija seljačkih radova. Beograd: Službeni glasnik. 1725. [Na ćirilici]

Lukić, R. (2012b). Predgovor. U: Vukosavljević, S. (2012e). Istorija seljačkog društva VI - Pisma sa sela, Politički i drugi spisi. Beograd: Službeni glasnik. 17-23. [Na ćirilici]

Marković, S. (1995). Celokupna dela - knjiga VII. Beograd: SANU - Zavod za udžbenike i nastavna sredstva. [Na ćirilici]

Milošević, B. (1997). Umeće rada. Novi Sad: Filozofski fakultet.

Mitrović, M. (?) Sreten Vukosavljević biografija MS; preuzeto 28.01.2020. sa http://www.maticasrpska.org.rs/stariSajt/biografije/biografije_sbr.pdf

Mitrović, M. (1998). Sociologija sela. Beograd: Srpsko sociološko društvo. [Na ćirilici]

Mitrović, M. (2012a). Sociološka istorija i istorijska sociologija srpskog seljačkog društva. U: Isić, M. -Mitrović, M. -Aranitović, D. (2012). Život i delo Sretena Vukosavljevića 1881-1960. Beograd: Službeni glasnik. 125-155. [Na ćirilici]

Mitrović, M. (2012b). Prethodne napomene. U: Vukosavljević, S. (2012d). Istorija seljačkog društva $V$ - Seoske zajednice $i$ oblici ponašanja u njima. Beograd: Službeni glasnik. 13-23. [Na ćirilici]

Novakov, M. (2011). Porodični i društveni položaj majke u selu. Novi Sad: Poljoprivredni fakultet. [Na ćirilici]

Šaranović, B. (2012). Napomena ovom izdranju. Vukosavljević, S. (2012e). Istorija seljačkog društva VI - Pisma sa sela, Politički i drugi spisi. Beograd: Službeni glasnik. 25-26. [Na ćirilici]

Šljukić, M. (2019). Fabrika: industrija u post-socijalističkoj Srbiji. Novo Miloševo: Banatski kulturni centar. [Na ćirilici] 
Veselinov, D. (1987). Sumrak seljaštva. Beograd: Ekonomika.

Vukosavljević, S. (1962). Pisma sa sela. Beograd: Savremena škola.

Vukosavljević, S. (2012a). Istorija seljačkog društva I - Organizovanje seljačke zemljišne svojine. Beograd: Službeni glasnik. [Na ćirilici]

Vukosavljević, S. (2012b). Istorija seljačkog društva III - Sociologija seljačkih radova. Beograd: Službeni glasnik. [Na ćirilici]

Vukosavljević, S. (2012c). Istorija seljačkog društva IV-Seoske ustanove i uredbe. Beograd: Službeni glasnik. [Na ćirilici]

Vukosavljević, S. (2012d). Istorija seljačkog društva V-Seoske zajednice i oblici ponašanja u njima. Beograd: Službeni glasnik. [Na ćirilici]

Vukosavljević, S. (2012e). Istorija seljačkog društva VI - Pisma sa sela, Politički $i$ drugi spisi. Beograd: Službeni glasnik. [Na ćirilici] 